\title{
Bioconcentration of ${ }^{203} \mathrm{HgCl}_{2}$ in Rainbow Trout and Carp at Low Concentrations
}

\author{
Meiko Wakabayashi, ${ }^{* 1}$ Mikio Kikuchi, ${ }^{* 1}$ Youn-Keun Oh, ${ }^{* 2}$ \\ Tamao Yoshida, ${ }^{* 3}$ Harumi Kojima, ${ }^{* 3}$ and Hodaka Saito*3 \\ (Accepted September 4, 1986)
}

\begin{abstract}
Rainbow trout Salmo gairdneri and carp Cyprinus carpio were exposed to ${ }^{203} \mathrm{HgCl}_{2}$ at a concentration of $0.5 \mu \mathrm{g}-\mathrm{Hg} / \mathrm{l}$.

At relatively short-term $(40 \mathrm{~h})$ exposure, the mean bioconcentration factor (BCF) of rainbow trout was affected by $\mathrm{pH}$ of buffered exposure solution and was high at low $\mathrm{pH}$ as compared with that in high $\mathrm{pH}$.

The $\mathrm{BCF}$ for the exposure of 17 days in the artificial water was about 800 for rainbow trout and carp, but the concentrations of ${ }^{203} \mathrm{Hg}$ in fishes and those in the solution were not in equilibrium. The profile of bioconcentration in the river water was similar to that in the artificial water. The equilibrium BCF estimated using a simple linear differential equation were several thousands.
\end{abstract}

The bioconcentration of organic mercurial compounds in fish has been studied extensively in relation to research works on the "Minamata" disease. However little has been reported on inorganic mercurial compounds, despite the fact that the dominant chemical forms of mercury in water and in sediments are inorganic. In Japan, the bioconcentration factor (BCF) of inorganic mercurial compounds is estimated at several tens. ${ }^{1)}$

Radoux and Bouquegneau reported that the level of mercury in Serranus cabrilla was equilibrated at approximately $2 \mu \mathrm{g}-\mathrm{Hg} / \mathrm{g}$-body weight after 4 days exposure to $\mathrm{HgCl}_{2}$ at a level of $100 \mu \mathrm{g}$ $\mathrm{Hg} / l^{22}$ However, the BCF was not given, and it may have been caused by that the decreasing rate of the mercury in the experimental solution was too high to calculate BCF. On the other hand, Mckone et al. reported that mercury levels of $40-50 \mu \mathrm{g} / \mathrm{g}$ were obtained in goldfish after 100 hours exposure to $250 \mu \mathrm{g} \mathrm{HgCl}_{2} / h^{\mathrm{s})}$ Although the mercury concentration in the fish body did not rearch equilibrium with the exposure solution in McKone's paper, the BCF at equilibrium could be estimated to be more than several hundred. Pentreath carried out the exposure studies at a very low level of $0.1 \mu \mathrm{g}-\mathrm{Hg} / l$ using ${ }^{203} \mathrm{HgCl}_{2}$, and reported $\mathrm{BCFs}$ of about 340 for plaice Pleuronectes platessa after
90 days exposure, ${ }^{4}$ and also about 500 for the thornback ray Raja clavata after 60 days exposure. ${ }^{5)}$ In his studies, the mercury level in the fish body did not reach an equilibrium as same as reported by McKone. Pentreath estimated the BCF at equilibrium using a linear differential equation to be about 1200 and 3700 for the plaice and for the thronback ray, respectively. These results show that BCFs of the inorganic mercury in fish are more than several hundred in magnitude.

According to the data of an environmental survey, fish caught in similar water concentrations even if in the same species and age group, showed a wide variation in their mercury contents. Environmental parameters such as $\mathrm{pH}$, water temperature, dissolved oxygen, and coexisting substances may affect on the bioconcentration of inorganic mercurial compounds in the fish body. Thus, further elaborated investigation is required on the bioconcentration of inorganic mercurial compounds.

In our previous studies, it has been found that the uptake of mercury in medaka Oryzias latipes exposed to ${ }^{203} \mathrm{HgCl}_{2}$ was dependent upon $\mathrm{pH}^{8)}$ and the concentration of various coexisting substances, such as humic acid. ${ }^{\text {? }}$

*1 The Tokyo Metropolitan Research Institute for Environmental Protection, Shinsuna 1, Koto, Tokyo 136, Japan (若林明子, 菊地幹夫：東京都環境科学研究所).

*2 Department of Oceanography and Marine Resources, Fisheries Research and Development Agency 2-16, Namhang-Dong, Youngdo-Ku, Pusan, Korea (受 潤裉：韓国国立水産振興院海洋資源部).

*3 Department of Marine Environmental Science and Technology, The Tokyo University of Fisheries, Konan 4, Minato, Tokyo 108, Japan (吉田多糜夫, 小島はるみ, 齐藤稜高: 東京水産大学海洋環境工学科). 
The purpose of this paper is to clarify the bioconcentration profile of $\mathrm{HgCl}_{2}$ in rainbow trout Salmo gairdneri and carp Cyprinus carpio, the key fishes of the inland fisheries.

\section{Materials}

\section{Chemicals}

${ }^{209} \mathrm{HgCl}_{2}$ was obtained from New England Nuclear. The specific radioactivity was 3.2-6.7 $\mathrm{mCi} / \mathrm{mg}$. ${ }^{203} \mathrm{HgCl}_{2}$ was dissolved to $0.1 \mathrm{~N}-\mathrm{HCl}$ solution or $0.4 \mathrm{~N}-\mathrm{HCl}$ solution.

\section{Fish}

Eyed eggs of rainbow trout obtained from the Tokyo Metropolitan Fisheries Experimental Station were hatched and kept in the laboratory. In this experiment, about 3-months-old rainbow trout were used. The carp were obtained from the station two weeks prior to the experiment, were maintained in the laboratory, and were 1-2 months old when used. Both fishes were in good physical condition.

\section{Water}

An artificial water was prepared by adding salts to distilled water so that the salt content was 26.1 $\mathrm{mg} / l$ as $\mathrm{CaCl}_{2} \cdot 2 \mathrm{H}_{2} \mathrm{O}, 17.7 \mathrm{mg} / l$ as $\mathrm{MgSO}_{2} \cdot 7 \mathrm{H}_{2} \mathrm{O}$, $1.1 \mathrm{mg} / l$ as $\mathrm{MgSO}_{4}$ and $25 \mathrm{mg} / \mathrm{l}$ as $\mathrm{NaHCO}_{8}$. The hardness of the artificial water was $25 \mathrm{mg} / l$ as $\mathrm{CaCO}_{3}{ }^{32}$ ) The river water was collected at the Hamura section of the Tama River. The hardness and total organic carbon of the river water were about $40 \mathrm{mg} / \mathrm{l}$ and $2-3 \mathrm{mg} / \mathrm{l}$, respectively.

\section{Methods}

\section{Short-term Exposure}

Buffer solutions of $\mathrm{pH} \mathrm{5,7}$ and 9 were prepared by adding $\mathrm{KH}_{2} \mathrm{PO}_{4}$ and/or $\mathrm{K}_{2} \mathrm{HPO}_{4}$ to the artificial water. An exposure solution was prepared by adding $5 \mathrm{ml}$ of ${ }^{203} \mathrm{HgCl}_{2}$ solution (in $0.1 \mathrm{~N}$ $\mathrm{HCl})$ to $5 l$ of the buffer solution, and the $\mathrm{pH}$ of the exposure solution was adjusted exactly by $0.1-$ $\mathrm{N} \mathrm{NaOH}$ solution. Concentration of ${ }^{203} \mathrm{Hg}$ and phosphate ion of each exposure solution was about $0.5 \mu \mathrm{g} / l$ and $2 \mathrm{~mm}$, respectively. The exposure solution was prepared $1-2 \mathrm{~h}$ before the beginning of the exposure or changing of the solution in order to depress the decrease of ${ }^{203} \mathrm{Hg}$ concentration of the solution during the exposure.

Three groups of 9-10 rainbow trout, $0.60 \pm$ $0.11 \mathrm{~g}$ (mean $\pm \mathrm{SD}$ ) of body weight, were exposed to the solution of $\mathrm{pH} 5,7$ or 9 , respectively, at a temperature of $16.8-17.2^{\circ} \mathrm{C}$. The mass/volume ratio never exceeded $1.4 \mathrm{~g}$ of the fish per liter of the solution. In addition, three groups of 29-30 carp, $0.17 \pm 0.03 \mathrm{~g}$ of body weight, were also likewise exposed to the solution of $\mathrm{pH} 5,7$ or 9 at a water temperature of $20.4-22.4^{\circ} \mathrm{C}$. The mass/volumn ratio never exceeded $1.2 \mathrm{~g}$ of the fish per liten of the solution. Food was withheld 2 days prior to and throughout the exposure. After 13 and $26 \mathrm{~h}$, the exposure solutions were changed. After $40 \mathrm{~h}$ exposure all fishes were removed from the aquariums. The fish were anesthetized with 2-phenoxyethanol and washed in tap water to remove any adhering ${ }^{209} \mathrm{Hg}$. The radioactivity of the fish and exposure solution was measured using a vial-type gamma scintillation counter (Shimazu Auto Well Counter RAW-300) and the BCF of the ${ }^{203} \mathrm{Hg}$ was calculated.

\section{Long-term Exposure}

An exposure solution was prepared by adding $3 \mathrm{ml}$ of the ${ }^{200} \mathrm{HgCl}_{2}$ solution (in $0.4 \mathrm{~N}-\mathrm{HCl}$ ) to $10 \mathrm{l}$ of the artificial water or the river water and the $\mathrm{pH}$ of the solution was adjusted to $\mathrm{pH} 7$ by $0.5 \mathrm{~N}$ $\mathrm{NaOH}$ solution. Concentration of ${ }^{203} \mathrm{Hg}$ was about $0.5 \mu \mathrm{g} / l$.

One group of 26 rainbow trout were exposed to ${ }^{203} \mathrm{HgCl}_{2}$ solution of the artificial water at a temperature of $15-19^{\circ} \mathrm{C}$. Another group of 10 rainbow trout were likewise exposed to ${ }^{203} \mathrm{HgCl}_{2}$ solution of the river water. Their body weight was $0.78 \pm 0.20 \mathrm{~g}$. In addition, one group of 38 carp were exposed to ${ }^{203} \mathrm{HgCl}_{2}$ solution of the artificial water at a temperature of $20-22^{\circ} \mathrm{C}$. Another group of 33 carp were likewise exposed to ${ }^{203} \mathrm{HgCl}_{2}$ solution of the river water. Body weight of the carp was $0.17 \pm 0.05 \mathrm{~g}$. The mass/volume ratio never exceeded $2 \mathrm{~g}$ of the fish per liter of the solution. The solution was exchanged every day. Rainbow trout were fed dry commereial trout pellet at $3 \%$ of body weight at 9th, 12th and 15th day from the beginning of the exposure. Carp were also fed same pellet every two days. After $0.25,1,3,6$, 11,14 and 17 days exposure, 2-13 fish were removed from the aquarium and analyzed. The fish were anesthetized with MS222 (m-(ethoxycarbonyl)anilinium methanesulfonate) and washed in tap water to remove any adhering ${ }^{208} \mathrm{Hg}$. The radioactivity of the fish and exposure solution was measured using vial-type gamma scintillation counter (Aloka Model NDW-51) and the BCF of ${ }^{203} \mathrm{Hg}$ was calculated. 
Table 1. The mean concentration of ${ }^{203} \mathrm{HgCl}_{2}$ in the exposure solution of the short-term experiment

\begin{tabular}{cc}
\hline Solution & $\begin{array}{c}\text { Concn. of }{ }^{203} \mathrm{Hg}^{* 1}, \\
\mu \mathrm{g} / l\end{array}$ \\
\hline Experiment of rainbow trout*2 \\
pH 9 & $0.49 \pm 0.03$ \\
pH 7 & $0.48 \pm 0.02$ \\
pH 5 & $0.50 \pm 0.01$ \\
Experiment of carp*3 & \\
pH 9 & $0.55 \pm 0.02$ \\
pH 7 & $0.53 \pm 0.02$ \\
pH 5 & $0.58 \pm 0.02$
\end{tabular}

*
* $\mathrm{n}=36$ (in each run).

*3 $n=24$ (in each run).

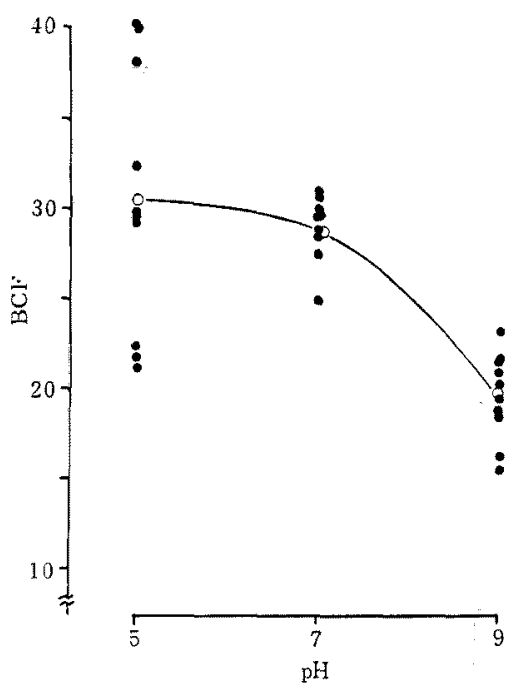

Fig. 1. The effect of $\mathrm{pH}$ on the bioconcentration of ${ }^{203} \mathrm{Hg}$ in rainbow trout exposed to ${ }^{203} \mathrm{HgCl}_{2}$ for $40 \mathrm{~h}$. Open symbols represent the mean values obtained in each exposure.

\section{Results and Discussion}

\section{Influence of $p H$ on the $B C F$}

The concentration of ${ }^{203} \mathrm{Hg}$ in each solution throughout exposure are shown in Table 1. The standard deviation of the ${ }^{203} \mathrm{Hg}$ concentration was $2-6 \%$ and $3-4 \%$ in the experiment of carp and rainbow trout, respectively. Fluctuation of the levels of ${ }^{203} \mathrm{Hg}$ in this experiment was small. The presence of phosphate ions could be attributed to depressing the decrease of ${ }^{203} \mathrm{Hg}$.

The results for the rainbow trouts are shown in Fig. 1 and the BCFs are $19.7 \pm 2.4,28.9 \pm 1.8$ and $30.4 \pm 7.3$ at $\mathrm{pH} 9,7$ and 5 , respectively. A wide

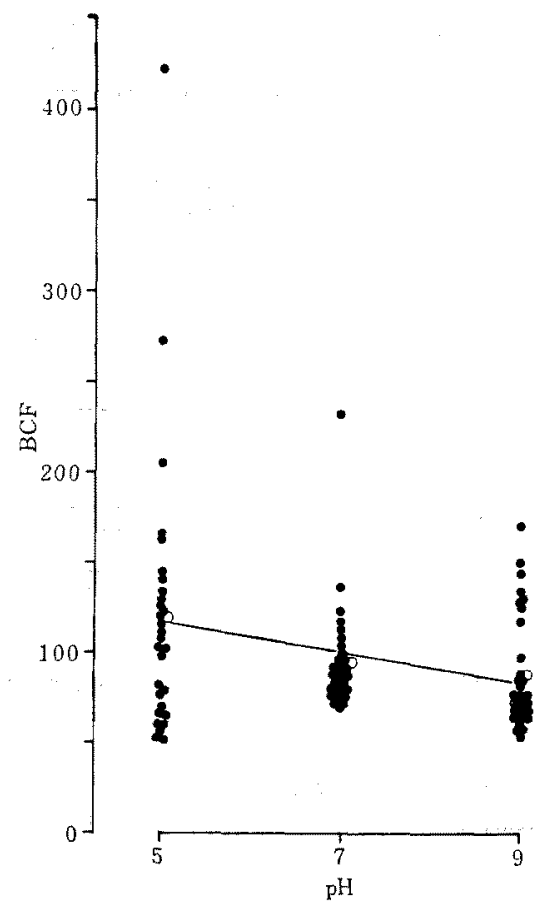

Fig. 2. The effect of $\mathrm{pH}$ on the bioconcentration of ${ }^{203} \mathrm{Hg}$ in carp exposed to ${ }^{203} \mathrm{HgCl}_{2}$ for $40 \mathrm{~h}$. Open symbols represent the mean values obtained in each exposure.

variation of the $\mathrm{BCFs}$ was observed at $\mathrm{pH} 5$. The mean BCFs were similar between $\mathrm{pH} 7$ and $\mathrm{pH} 5$ but a clear difference was found in the BCFs between $\mathrm{pH} 9$ and $\mathrm{pH} 5$. The results for the carp are shown Fig. 2. The BCFs were $89.3 \pm 32.2$, $94.4 \pm 30.4$ and $120 \pm 76$ at $\mathrm{pH} \mathrm{9,7}$ and 5 , respectively. The BCFs for carp at all $\mathrm{pH}$ levels tested were three to five times higher than that of the rainbow trout. At $\mathrm{pH} 5$, a marked variation was observed in the carp. The mean $\mathrm{BCF}$ at any $\mathrm{pH}$ was similar to each other. It is important that some fish concentrate ${ }^{203} \mathrm{Hg}$ highly at low $\mathrm{pH}$ in both fishes.

In our previous report, ${ }^{\theta)}$ the $\mathrm{BCF}$ of ${ }^{203} \mathrm{Hg}$ in medaka Olyzias latipes exposed to ${ }^{200} \mathrm{HgCl}_{2}$ at ppb level for $40 \mathrm{~h}$ was affected by $\mathrm{pH}$ of the buffered exposure solution. Tsai et al. also reported that with lowering of $\mathrm{pH}$ of buffered exposure solution there was a remarkable increase in the uptake level of $\mathrm{Hg}$ in the fish exposed for $15 \mathrm{~min}$ at ppm level. These results show that some fishes living in a low $\mathrm{pH}$ water area, such as an acidic lake or a sea near a submarine volcano, 


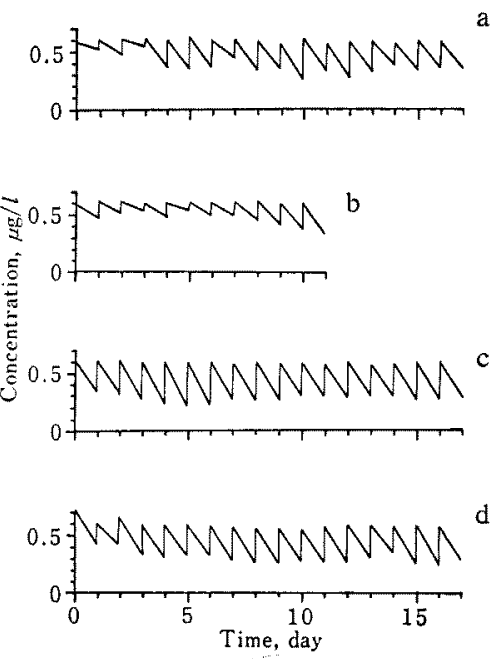

Fig. 3. Time-course changes of ${ }^{203} \mathrm{Hg}$ concentration in the exposure solution of (a) artificial water (rainbow trout), (b) river water (rainbow trout), (c) artificial water (carp), and (d) river water (carp).

may concentrate mercury at a high level.

\section{Long Exposure}

Daily fluctuations in ${ }^{203} \mathrm{Hg}$ concentrations in the exposure solution of artificial water or river water are shown in Fig. 3. Mean ${ }^{203} \mathrm{Hg}$ concentrations with standard deviation in each exposure solution for the rainbow trout were $0.49 \pm 0.12 \mu \mathrm{g} / l$ and $0.52 \pm 0.09 \mu \mathrm{g} / l$ for artificial water and river water, respectively. Those in the case of the carp in artificial water and river water were both $0.46 \pm 0.16$ $\mu \mathrm{g} / l$. It is difficult to maintain a constant concentration level of $\mathrm{HgCl}_{2}$ in diluted solutions at a ppb level. Removal of mercury from the solution could be mainly due to volatilization from the surface and adherance to the glass wall of aquarium. In this study, the decrease of ${ }^{203} \mathrm{Hg}$ concentration during the experiment was minimized by changing the exposure solution every day. A large decrease of ${ }^{203} \mathrm{Hg}$ was observed in the carp experiment where the water temperature was high in comparison to the rainbow trout experiment.

Time course observations of ${ }^{203} \mathrm{Hg}$ concentration in rainbow carp and trout are shown in Fig. 4 and Fig. 5, respectively. The ${ }^{203} \mathrm{Hg}$ level in the fishes increased throughout the exposure period and did not reach equilibrium in either case. The BCF of ${ }^{203} \mathrm{Hg}$ in rainbow trout was about 280,640

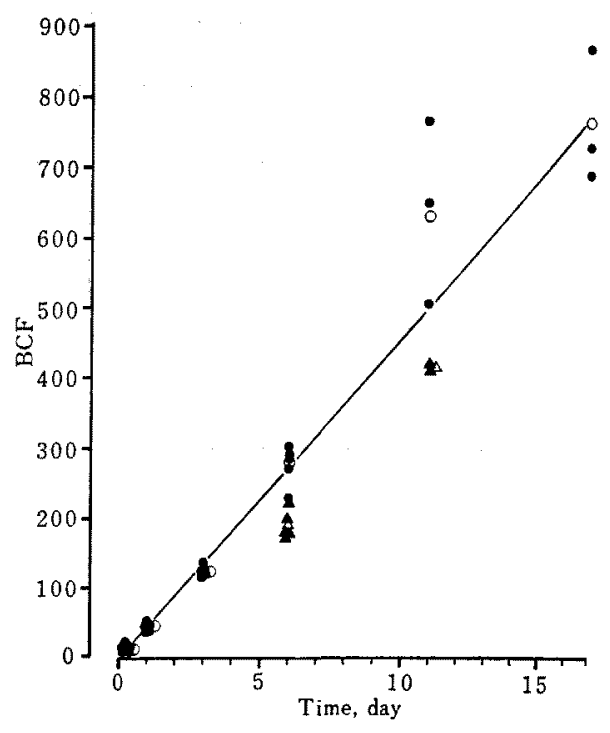

Fig. 4. Change of the BCF (wet basis) of ${ }^{203} \mathrm{Hg}$ in rainbow trout exposed to ${ }^{203} \mathrm{HgCl}_{2}$. Open symbols represent the mean values obtained in each exposure.

0 Artificial water; $\Delta \triangle$ River water

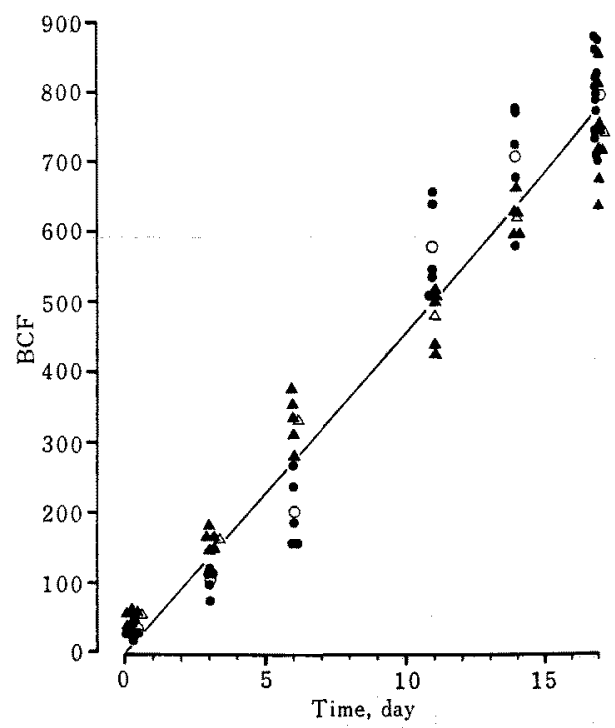

Fig. 5. Change of the BCF (wet basis) of ${ }^{203} \mathrm{Hg}$ in carp exposed to ${ }^{203} \mathrm{HgCl}_{2}$. Open symbols represent the mean values obtained in each exposure.

- Artificial water; $\Delta \Delta$ River water

or 760 for the exposures of 6,11 or 17 days in artificial water, respectively, In river water it 
was 190 or 410 at days 6 or 11 . In carp, the BCF for exposure of 6,11 or 17 days to artificial water were 200,570 , or 790 , respectively. In river water, the BCF was 330,480 or 740 , respectively. The BCFs obtained for the exposure to artificial water and river water were similar in both case of rainbow trout and carp. The levels of substances which affect the bioconcentration of mercury in fish, such as humic acids, in the river water might be low enough not to affect. A BCF interpolated at $40 \mathrm{~h}$-exposure in carp of this experiment without phosphate buffer was similar to an apparent BCF obtained in the short-term exposure experiment in phosphate buffered solution. This indicates that phosphate buffer does not affect the BCF in carp. However, in the case of rainbow trout, the BCF is lower in the phosphate buffered solution than in the phosphate free solution.

The bioconcentration of ${ }^{203} \mathrm{Hg}$, expressed as a $B C F$, was described by a simple linear differential equation. ${ }^{4)}$

$$
\begin{aligned}
& C_{t}=C_{s \mathrm{~s}}\left(1-\mathrm{e}^{-\mathrm{k} t}\right) \\
& \mathrm{k}=0.693 / \mathrm{t}_{\mathrm{b} 1 / 2}
\end{aligned}
$$

where $C_{83}$ is the equilibrium $B C F$ and $t_{b 1 / 2}$ is the biological half-life. Assuming the biological halflife is about 100 days from the data of other authors, ${ }^{2)}$ the $C_{88}$ values of rainbow trout and carp in artificial water were calculated to be both about 5,000 . That is, rainbow trout and carp concentrate high levels of $\mathrm{HgCl}_{2}$ when they are exposed to it at low concentrations. From the results obtained by us on freshwater fishes and obtained by Pentreath on marine fishes, $\mathrm{HgCl}_{2}$ in the environment may be concentrated in fishes at a $\mathrm{BCF}$ of several thousands.

\section{References}

1) Central Council for Environmental Pollution Control: Change on environmental quality standards and the waste water discharge standards relating to mercury and relevant measuring methods 1964 .

2) D. Radoux and J. M. Bouquegneau: Bull. Environ. Contam. Toxicol., 22, 771-778 (1979).

3) C. E. McKone, R. G. Young, C.A. Bache, and D. J. Lisk: Environ. Sci. Technology, 5, 11381139 (1971).

4) R. J. Pentreath: J. exp. mar. Biol., 24, 103-119 (1976).

5) R. J. Pentreath: J. exp. mar. Biol., 25, 131-140 (1976).

6) Y.-K. Oh, H. Kojima, T. Yoshida, M. Wakabayashi, and M. Kikuchi: Nippon Suisan Gakkaishi, 52, 165 (1986).

7) Y.-K. Oh, T. Yoshida, H. Kojima, M. Wakabayashi, and M. Kikuchi: Nippon Suisan Gakkaishi, 52, 1653-1656 (1986).

8) K. Tabata: J. Wat. Waste., 14, 1297-1303 (1972).

9) S. C. Tai, G.M. Boush, and F. Matsumura: Bull. Environ. Contam. Toxicol., 13, 188-193 (1975). 